\title{
Late Cardio-Pulmonary Sequelae after Treatment of Hodgkin's Disease (HD)
}

\author{
A. Abaza \\ Radiation Protection Dept., National Centre of Radiation \\ Protection and Safety Control (NCRPSC), P. O. Box: 29 Nasr \\ City, Egypt.
}

\begin{abstract}
TODGKIN'S disease patients regularly attending the - 1 paediatric oncology clinic of National Cancer Institute (NCI), Cairo University were studied to identify the late effects of radio- chemotherapy on the pulmonary and cardiovascular system in long-term survivors (LTS). A group of 42 LTS were studied, together with 26 newly-diagnosed (ND) HD patients and 28 healthy controls, during a 3 years period. The systolic and diastolic blood pressure-mean difference from the $90^{\text {th }}$ percentile of age and sex-matched groups were higher in LTS and ND patients ( $P<0.051$ and $P<0.003$, respectively). Systolic hypertension occurred in $9.5 \%$ of the LTS patients. Serum triglycerides (TG) were significantly elevated in LTS \& ND patients $(p \leq 0.001)$. Anaemia was significantly higher in ND patients. Pulmonary infiltrations were detected in $4.8 \%$ of LTS, and $2.3 \%$ had plural thickening. One patient only $(2.38 \%)$ of the LTS had constrictive pericarditis. Finally, the study documented that systolic hypertension, and a cardio-pulmonary complication was one of the long-term sequelae of radiochemotherapy in HD patients. Recommendations regarding the follow-up of therapy for HD were discussed. New strategies and evidence-based surveillance of the long-term effects will be needed for dealing with HD, especially in children.

Keywords: late effects, therapy, Hodgkin's disease.
\end{abstract}

Hodgkin's lymphoma (HL) in children can now successfully be treated with overall survival exceeding 90\%. Treatment for paediatric HL consists of radiotherapy (RT), chemotherapy (CTH), or a combination of both (van Beek et al., 2009). Although most studies have achieved desired survival outcomes, data on late effects of therapy await LT follow-up studies (Chow et al., 2006). Pulmonary radiation can lead to pulmonary fibrosis and pneumonitis. Clinically apparent pneumonitis with cough, fever, or dyspnea occurs in 5\%-15\% of 
patients who received more than $30 \mathrm{~Gy}$ in standard fractions to more than 50\% of the lung. Obstructive changes have also been reported after conventional radiation therapy (Griese et al., 2000). Irradiation of up to 25 Gy to the heart showed little or no cardiac toxicity. Doses of $>25 \mathrm{~Gy}$ led to several cardiac dysfunctions. However, chronic cardiac toxicity can occur with radiation doses exceeding 40 Gy (Adams et al., 2003). Chronic cardiotoxicity usually manifests itself as cardiomyopathy, pericardial effusions, pericarditis, and congestive heart failure (HF) (Bhatia, 2005). The anthracyclines (e.g., doxorubicin, daunomycin and idarubicin) are well-known causes of cardiomyopathy (Grenier and Lipshultz, 1998). The incidence of cardiomyopathy is dose-dependent and may exceed $30 \%$ among patients who received a cumulative anthracycline dose in excess of $600 \mathrm{mg} / \mathrm{m}^{2}$. With a total dose of 500 to $600 \mathrm{mg} / \mathrm{m}^{2}$, the incidence is $11 \%$, falling to less than $1 \%$ for cumulative doses less than $500 \mathrm{mg} / \mathrm{m}^{2}$ (Bhatia, 2005). A cumulative dose of greater than $250 \mathrm{mg} / \mathrm{m}^{2}$ (in association with radiation to the heart) was associated with a higher risk of clinical HF compared with a cumulative dose lower than $250 \mathrm{mg} / \mathrm{m}^{2}$ (5\%) (Pein et al., 2004). Several chemotherapeutic agents are also responsible for pulmonary disease in LTS as bleomycin, carmustine (BCNU) and lomustine (CCNU). Interstitial pneumonitis and pulmonary fibrosis have been reported in children exposed to these drugs, with the chronic lung toxicity being dose-dependent and exacerbated by concurrent or previous RT (Bhtia, 2005).

The present study aimed to identify the late pulmonary and cardiovascular sequelae of RT and/or CTH on HD-LTS regularly attending the paediatric oncology clinic of NCI, Cairo University, during the 3 years period.

\section{Subjects and Methods}

The patients were classified into two groups:

First group; LTS: 42 patients (33 males and 9 females) who completed therapy for HD and off therapy more than 5 years. Their ages ranged from 9-22 years with a mean of $14.9 \pm 3.4$ years and median age of 15.5 years. The mean follow up time was $7.47 \pm 2.19$ years (median $6.75 \& 6.75$ years). Second group; ND: 26 patients (15 males and 11 females) prior to any type of treatment. Their ages ranged from 4-15 years with a mean of $9.5 \pm 3.7$ years and median age of 8.5 years. The control group: 28 healthy age and sex matched normal children (15 males and 13 females). All patients were subjected to:

Egypt. J. Rad. Sci. Applic., Vol. 24, No. 2 (2011) 


\section{Clinical history and examinations}

Files of the LTS were revised for the date of diagnosis and end of treatment, original site(s), staging, histopathological subtype and dose \& duration of therapy. Clinical examinations included blood pressure, pulse, and chest/heart examination, visceromegaly and the presence of lymphadenopathy.

\section{Laboratory investigations included}

Complete haemogram was done for all groups and bone marrow examination for ND and LTS only. The blood lipid and lipoproteins assay was done for all groups.The estimation was carried out on a fully automated analyzer Hitachi 717. LDL-cholesterol (LDL) levels were estimated by calculation using (Friedewald et al., 1972) formula Cholesterol - (Triglycerides + HDL)/ 5

\section{Radiological studies were performed including}

Plain X-rays of chest was done for LTS and ND patients for mediastinal shadows and lung infiltration or fibrosis. CT chest was indicated in 7 ND patients to confirm the diagnosis. Echocardiography was done in all LTS to evaluate for any cardiac complications.

\section{Treatment modalities}

The chemotherapeutic regimens used alone or in combination were $M O P P$ (Mechlorethamine, Oncovin, Procarbazine \& Prednisone), ABVD (Adriamycine, Bleomycin, Vinblastine \& Dacarbazine), OPPA (Adriamycine, Vincristine, Procarbazine \& Prednisone), COPP (cyclophosphamide, Vincristine, Procarbazine \& Prednisone) Table (1\&2).

TABLE 1. Radiotherapy schedule of LTS.

\begin{tabular}{|c|c|c|}
\hline Types of radiotherapy & No $(\%)$ & Dose of fractionated irradiation (Gy) \\
\hline $\begin{array}{l}\text { Involved field (IF) } \\
* \text { Whole neck } \\
* \text { Mediastinal } \\
* \text { Inguinal }\end{array}$ & $\begin{array}{l}18(58.1) \\
3(9.7) \\
2(6.5)\end{array}$ & $\begin{array}{l}25-40 \\
22-26 \\
22-40\end{array}$ \\
\hline $\begin{array}{l}\text {-Mantle } \\
\text {-Inverted Y (IY) } \\
\text {-Whole neck+ Whole abdomen + IY } \\
\text {-Cranial irradiation+ IY } \\
\text {-Whole neck+ IY }\end{array}$ & $\begin{array}{l}1(3.2) \\
4(12.9) \\
1(3.2) \\
1(3.2) \\
1(3.2) \\
\end{array}$ & $\begin{array}{c}23.5 \\
25-30 \\
30+15+15 \\
24+25.2 \\
34+36 \\
\end{array}$ \\
\hline Total & $31(100)$ & ------- \\
\hline
\end{tabular}

Egypt. J. Rad. Sci. Applic., Vol. 24, No. 2 (2011) 
TABLE 2. Treatment modalities in LTS.

\begin{tabular}{|l|c|c|c|c|}
\hline \multicolumn{1}{|c|}{ Type } & No. & \% & Total & \% \\
\hline Radiotherapy alone: & \multicolumn{2}{|c|}{$-{ }^{---}$} & 1 & 2.4 \\
$\quad$ IF & & & & \\
\hline Chemotherapy alone: & 8 & 19.0 & & \\
MOPP & 1 & 2.4 & 11 & 26.2 \\
MOPP+ ABVD & 2 & 4.8 & & \\
MOPP+ Others & & & & \\
\hline Chemo-radiotherapy: & 12 & 28.5 & & \\
MOPP & 4 & 9.5 & & \\
MOPP+ ABVD & 4 & 9.5 & 30 & 71.4 \\
OPPA & 2 & 4.8 & & \\
MOPP+ OPPA & 2 & 4.8 & & \\
MOPP+ OPPA+ ABVD & 6 & 14.3 & & \\
Other regimens including COPP & & &
\end{tabular}

\section{Statistical analysis}

Statistical Package for Social Sciences (SPSS) version 6.3.5. was used Mean, standard deviation, t-test and ANOVA-test were applied whenever indicated. $P$-value is always two-tailed and is significant $\leq 0.05$ (Winters et al., 2010).

\section{Results}

The results of the present work are presented in Table (3-7).

TABLE 3. Clinical characteristics and sequelae of HD patients.

\begin{tabular}{|c|c|c|}
\hline \multirow{2}{*}{ Item } & LTS & ND \\
\hline & No $(\%)$ & No $(\%)$ \\
\hline Stage & & \\
\hline I & $15(35.7 \%)$ & $9 \quad(34.6 \%)$ \\
\hline II & $10(23.8 \%)$ & $8 \quad(30.8 \%)$ \\
\hline III & $15(35.7 \%)$ & $8 \quad(30.8 \%)$ \\
\hline IV & $2(4.8 \%)$ & $1 \quad(3.8 \%)$ \\
\hline Pathology & & \\
\hline L.P. & $7 \quad(16.7 \%)$ & $4 \quad(15.4 \%)$ \\
\hline M.C. & $23(54.8 \%)$ & $14(53.8 \%)$ \\
\hline N.S. & $9 \quad(21.4 \%)$ & $7 \quad(26.9 \%)$ \\
\hline U.N. & $3(7.1 \%)$ & $1(3.8 \%)$ \\
\hline Heart rate & & \\
\hline Normal & $35(83.4 \%)$ & $19(73.1 \%)$ \\
\hline Tachycardia & $4(9.5 \%)$ & $7 \quad(26.9 \%)$ \\
\hline Bradycardia & $3(7.1 \%)$ & $0 \quad(0.0 \%)$ \\
\hline
\end{tabular}

L.P.= Lymphocytic predominance. $\quad$ M.C.= Mixed cellularity. $\quad$ N.S.= Nodular sclerosis. U.N.= Unknown type.

Egypt. J. Rad. Sci. Applic., Vol. 24, No. 2 (2011) 
The presenting stage of the disease was stage I \& III (35.7\% for each) followed by stage II in LTS, versus stage I (34.6\%) followed by stage II $(30.8 \%)$ and III $(30.8 \%)$ in ND patients. The predominant subtype of HD was similar in LTS and ND patients: mixed-cellularity (54.8\%, 53.8\%, respectively) followed by nodular sclerosis $(21.4 \%, 26.9 \%$, respectively), Table 3 .

Tachycardia (above 100 beat/min) was found in 4 out of the 42 LTS (9.5\%) and 7 out of the $26 \mathrm{ND}$ cases (26.9\%). On the other hand, bradycardia (below 60 beat $/ \mathrm{min}$ ) was found in $3(7.1 \%)$ LTS and in none of the ND patients and its significance is shown in Table 3.

TABLE 4. Comparison of blood pressure as difference from $90^{\text {th }}$ percentile of corresponding group of same sex and age.

\begin{tabular}{|c|c|c|c|}
\hline Item & $\begin{array}{c}\text { LTS }(\text { X } \pm \text { S.D. }) \\
(\text { No. }=42)\end{array}$ & $\begin{array}{c}\text { ND }(X \pm \text { S.D. }) \\
(\text { No.= 26) }\end{array}$ & $P$-Value \\
\hline SBP difference & $6.7 \pm 18.9$ & $5.4 \pm 14.4$ & 0.051 \\
DBP difference & $10.9 \pm 10.6$ & $2.9 \pm 10.3$ & 0.003 \\
\hline
\end{tabular}

SBP difference $=90^{\text {th }}$ percentile-SBP. DBP difference $=90^{\text {th }}$ percentile-DBP.

The systolic and diastolic blood pressure mean-difference as compared to the 90th percentile of corresponding group of age and sex according to Bernstein (1996) was higher in LTS and ND patients and was found to be statistically significant between both groups; $P=0.051$ and 0.003 , respectively, (Table 4).

TABLE 5. Haemogram findings of the three groups.

\begin{tabular}{|c|c|c|c|c|}
\hline Items & $\begin{array}{c}\text { LTS } \\
\text { No. }(\%)\end{array}$ & $\begin{array}{c}\text { ND } \\
\text { No. }(\%)\end{array}$ & $\begin{array}{l}\text { Cont. G } \\
\text { No. }(\%)\end{array}$ & $P$-Value \\
\hline $\begin{array}{c}\text { Haemoglobin } \\
\text { Low HB } \\
\text { Normal }^{*}\end{array}$ & $\begin{array}{l}19(45.2 \%) \\
23(54.8 \%)\end{array}$ & $\begin{array}{c}19(73.1 \%) \\
7(26.9 \%)\end{array}$ & $\begin{array}{c}3(11.5 \%) \\
23(88.5 \%)\end{array}$ & $\begin{array}{c}0.0001 \\
\mathrm{~S} .\end{array}$ \\
\hline $\begin{array}{l}\text { TLC } \\
<4,000 \\
>11,000 \\
\text { Normal }^{* *}\end{array}$ & $\begin{array}{c}5(11.9 \%) \\
4(9.5 \%) \\
33(78.6 \%)\end{array}$ & $\begin{array}{c}2(7.7 \%) \\
2(7.7 \%) \\
22(84.6 \%)\end{array}$ & $\begin{array}{c}3(11.5 \%) \\
4(15.4 \%) \\
19(73.1 \%)\end{array}$ & $\begin{array}{l}0.856 \\
\text { N.S. }\end{array}$ \\
\hline $\begin{array}{l}\text { Platelet: } \\
\quad<150,000 \\
\text { Normal }^{* * *}\end{array}$ & $\begin{array}{c}3(7.1 \%) \\
39(92.9 \%)\end{array}$ & $\begin{array}{c}1(3.8 \%) \\
25(96.2 \%)\end{array}$ & $\begin{array}{c}2(7.7 \%) \\
24(92.3 \%)\end{array}$ & $\begin{array}{l}0.820 \\
\text { N.S. }\end{array}$ \\
\hline
\end{tabular}

Egypt. J. Rad. Sci. Applic., Vol. 24, No. 2 (2011) 
Anaemia was detected in $45.2 \%$ Of LTS versus $73.1 \%$ of ND patients. However, $11.5 \%$ of the controls were anaemic. The difference between groups was statistically highly significant $[\mathrm{p}<0.0001]$, Table 5 . The serum cholesterol (TC), HDL-C and LDL-C showed significantly decreased levels $(p<0.0004$, 0.001 and $<0.0001$, respectively), whereas the serum TG values were significantly elevated in LTS \& ND patients as compared to the normal $(\mathrm{p}=0.001)$ (Table 6).

TABLE 6. Serum lipid profile in the three groups.

\begin{tabular}{|c|c|c|c|c|}
\hline Items & $\begin{array}{c}\text { LTS Range } \\
\mathbf{X} \pm \mathbf{S D}(\mathrm{mg} \%)\end{array}$ & $\begin{array}{c}\text { ND Range } \\
\mathbf{X} \pm \text { SD }(\mathrm{mg} \%)\end{array}$ & $\begin{array}{c}\text { Cont. G Range } \\
\text { X } \pm \text { SD }(\mathrm{mg} \%)\end{array}$ & $P$-Value \\
\hline TC & $\begin{array}{c}100-180 \\
135.20 \pm 22.25\end{array}$ & $\begin{array}{c}79-197 \\
131.36 \pm 31.28\end{array}$ & $\begin{array}{c}106-191 \\
153.86 \pm 18.98\end{array}$ & 0.0004 \\
\hline TG & $\begin{array}{c}60-140 \\
100.2 \pm 20.82\end{array}$ & $\begin{array}{c}68-405 \\
167.12 \pm 68.33\end{array}$ & $\begin{array}{c}36-134 \\
73.9 \pm 22.47\end{array}$ & 0.0001 \\
\hline HDL & $\begin{array}{c}18-45 \\
25.62 \pm 5.34\end{array}$ & $\begin{array}{c}7-41 \\
22.76 \pm 7.89\end{array}$ & $\begin{array}{c}20-48 \\
35.76 \pm 6.68\end{array}$ & 0.001 \\
\hline LDL & $\begin{array}{c}20-135 \\
70.15 \pm 23.10\end{array}$ & $\begin{array}{c}24-146 \\
77.35 \pm 28.12\end{array}$ & $\begin{array}{c}64-147 \\
104.54 \pm 18.79\end{array}$ & 0.0001 \\
\hline
\end{tabular}

TC: Total cholesterol. TG: Triglyceride.

LDL-C: Low density lipoprotein-cholesterol.

HDL-C: High density lipoprotein-cholesterol.

Chest x-ray was abnormal in 5 male LTS (11.9\%) [2 had mediastinal lymphadenopathy, $2(4.8 \%)$ showed pulmonary infiltrations, and one $(2.3 \%)$ had plural thickening] versus $10(38.5 \%)$ of ND patients, as a part of the disease (Table 7). Echocardiography was abnormal in one patient only (2.38\%) of LTS which had constrictive pericarditis. This patient was treated with 6 cycles of MOPP/ABV and 30 Gy of mediastinal irradiation with a follow up period of 5 years after completion of therapy (Table 7).

TABLE 7. Late sequelae of HD patients.

\begin{tabular}{|l|c|c|}
\hline \multicolumn{1}{|c|}{ Items } & $\begin{array}{c}\text { LTS } \\
\text { No. (42) \% }\end{array}$ & Type of therapy \\
\hline Pulmonary sequelae: & $5(11.9 \%)$ & \\
Mediastinal lymphadenopathy & $2(4.8 \%)$ & MOPP/ABVD/OPPA/COPP+ \\
Pulmonary infiltrations & $2(4.8 \%)$ & Other regimens+ 50-70 Gy RT \\
Plural thickening & $1(2.3 \%)$ & \\
\hline Cardiac sequelae: & $1(2.38 \%)$ & \multirow{2}{*}{ MOPP/ABV + 30 Gy RT } \\
Constrictive pericarditis & $1(2.38 \%)$ & \\
\hline
\end{tabular}

Egypt. J. Rad. Sci. Applic., Vol. 24, No. 2 (2011) 


\section{Discussion}

Improvements in childhood cancer therapy have led to increasing numbers of LTS. These survivors are at risk for a variety of late effects due to the disease itself, and treatment exposures (Jones et al., 2008). In the present study, systolic hypertension occurred in $9.5 \%$ (4/42) of LTS. This may be due to essential hypertension (with negative family history in 4 patients), or renal parenchymal scaring secondary to radio-CTH. Talvensaar et al (1996) reported an elevation of systolic blood pressure in LTS, with a mean of $124 \pm 13 \mathrm{mmHg}$ in alignment with the presently documented $126.48 \pm 6.2 \mathrm{mmHg}$. Renal artery stenosis (with increased renin secretion from the juxtaglomerular apparatus and 2ry hypertension) has been reported as a rare complication of RT in children who were treated during infancy. However, to prevent symptomatic radiation nephropathy, combined modality treatment regimens should be carefully planned with particular care when given drugs metabolized through renal excretion (Eifel, 1994).

Anaemia was significantly higher in ND patients $(73.31 \%)$ versus $45.2 \%$ in LTS and $11.5 \%$ in the controls. Anaemia in HD may result from impaired mobilization of iron stores or may indicate the presence of advanced disease (bone marrow infiltration and/or failure) (Munker et al., 1995). After CTH, pure red cell aplasia may occur due to T-cell mediated suppression of erythropoiesis, where the response to cyclosporin may be masked by inappropriately low erythropoietin levels (Reid et al., 1994 and Mohri et al., 1997). After 40 Gy of irradiation, the maximum depression of marrow activity occur 6 month postirradiation; however, the hemopoietic activity within the irradiated area may be depressed for years. The recovery of the hemopoietic activity is dependent on volume of irradiated marrow, the age of the patient at the time of irradiation and the dose of irradiation (Eifel, 1994).

The risk associations between lipid/lipoprotein levels and different types of cancer remain controversial and largely unexplored (Yang et al., 2008). In the current study, there were significant elevation in the serum TG values with significantly decreased levels of serum-TC, HDL-C and LDL-C in LTS \& ND patients as compared to the normal which is in agreement with the findings of (Fiorenza et al., 2000 and Musolino et al., 2002). Many studies have reported a return to normal values of lipid profile after effective CTH. Previous studies have found that certain malignant cell types have elevated LDL receptor activity and that the possibility of LDL-C consumption by tumor cells causes hypo-

Egypt. J. Rad. Sci. Applic., Vol. 24, No. 2 (2011) 
cholesterolaemia. Lipid parameters are therefore considered as reliable markers of complete remission and may be useful in the follow up of cancer patients. However, there is paucity of information on the role and the profile of lipids and lipoprotein levels in hematological malignancies seen in Africans (Omoti and Idogun, 2009).

Curative therapy for childhood cancer has dramatically improved over past decades (Morris et al., 2009). Therapy-related radiation damage to the lung depends on the volume of lung tissue irradiated, the total dose received, and the fractionation schedule (Bölling et al., 2008). Monitoring for pulmonary dysfunction in childhood cancer survivors includes assessment of symptoms such as chronic cough or dyspnea on annual follow-up. Chest $\mathrm{x}$-ray is recommended as a baseline upon entry into long-term follow-up for patients at risk, or in patients with symptoms (Bhatia, 2005). In this study, Chest x-ray was abnormal in 5 male LTS (11.9\%) versus 10 (38.5\%) of ND patients. Several reports have been described radiation associated late sequelae after RT in childhood and adolescence, yet there is a lack of information about the dose effect relationships (Vordermark et al., 2006). The study of Tukenova et al., (2010) showed late cardiac mortality after much lower doses of $5 \mathrm{~Gy}$ to the heart after a long period of follow-up (average, 27 years) (Bolling and Willich, 2010). On the current study, only one case $(2.38 \%)$ of LTS had constrictive pericarditis after a mediastinal dose of $30 \mathrm{~Gy}$, with a follow up period of 5 years seen by echocardiography. This was in agreement with Chow et al (2006) who have only one patient $(2.3 \%)$ in first remission had an abnormal echocardiogram. This patient was treated with three cycles of MOPP/ABV and 15 Gy of EFRT and developed an asymptomatic increase in left-ventricular enddiastolic volume. It is well known that, the unique problem is mediastinal RT which may induce the development of the cardiomyopathy, constrictive pericarditis, coronary artery disease, myocardial infarction, valvular defects, arrhythmias and other complications (Hudecová et al., 2008). The risk of cardiac failure or severe abnormalities increases with adriamycin treatment, and also, with the dose of adriamycin and radiation received to the heart, without evidence for threshold (Pein et al., 2004). The little number of late cardiac complications in the present study may be due to short follow up period. Unfortunately, issues such as small sample sizes, single-institution populations, and short length of follow-up often have hindered the generalization of important findings (Mitby et al., 2003). However, many of the published reports are limited due to the small patient collectives. It is often difficult or impossible Egypt. J. Rad. Sci. Applic., Vol. 24, No. 2 (2011) 
to determine to what degree the late sequelae were due specifically to RT rather than to surgery or CTH. Other limitations in most of these analyses are inhomogeneous dose distributions, high single doses, and insufficient information on organ dose levels, and sometimes older radiation techniques that cannot be compared to modern RT. So, comparisons to current multimodal therapy approaches should therefore be made with caution (Bölling et al., 2010).

Finally the present study concluded that, after a mean follow-up time of $7.47 \pm 2.19$ years, there is a significant systolic hypertension, late pulmonary toxicity, constructive pericarditis, and significantly elevated serum TG in Egyptian HD-LTS. However, improvement in childhood cancer diagnosis and treatment with the resultant growing population of survivors has also resulted in increasing emphasis on research focusing on adverse health-related outcomes and identification of high-risk groups. Attention now needs to focus on development of intervention strategies, such as screening for early detection of late effects, and chemoprevention. Execution of these intervention strategies in the setting of clinical trials would allow us to understand the impact of the specific interventions in early detection, with an overall reduction in morbidity and mortality, by anticipating and preventing late complication, and an ultimate improvement in the overall quality of life of childhood cancer survivors.

\section{References}

Adams, M. J., Hardenbergh, P. H., Constine, L. S. and Lipshultz, S. E. (2003) Radiation-associated cardiovascular disease. Crit. Rev. Oncol. Hematol., 45, 55.

Bernstein, D. (1996) The cardiovascular system. In: Nelson Textbook of Pediatrics. W.E. Nelson, R.E. Behrman, R.M. Kliegman and A.M. Arvin (Eds), Part XX, Section 1, Chapter 380, 10th edition, W.B. Saunders Company, Philadelphia. pp. 1262.

Bhatia, S. (2005) Cancer survivorship-pediatric issues. Hematology., 2005, 507.

Bölling, T., Könemann, S., Ernst, I. and Willich, N. (2008) Late effects of thoracic irradiation in children. Strahlenther. Onkol., 184, 289.

Bölling, T. and Willich, N. (2010) Long-Term overall and cardiovascular mortality after childhood cancer: The problem of retrospective estimated radiation doses. J. Clin. Oncol., 28, e437.

Bölling, T., Willich, N. and Ernst, I. (2010) Late Effects of abdominal irradiation in children: A Review of the literature. Anticancer. Res., 30, 227.

Chow, L., Nathan, P., Hodgson, D., Jenkin, D., Weitzman, S., Grant, R., Manson, D., Bross, A., Doyle, J., Danjoux, C. and Greenberg, M. (2006) Survival and late effects in children with Hodgkin's lymphoma treated with MOPP/ABV and low-dose, extended-field irradiation. J. Clin. Oncol., 24, 5735.

Egypt. J. Rad. Sci. Applic., Vol. 24, No. 2 (2011) 
Eifel, P. J. (1994) Acute and chronic normal tissue effects and potential modification in pediatric radiation therapy. In: Radiation Therapy in Pediatric Oncology. J.R. Cassady (Ed.); $1^{\text {st }}$ edition, Springer-Verlag, Berline, Heidelberg. pp. 13.

Fiorenza, A. M., Branchi, A. and Sommariva, D. (2000) Serum lipoprotein profile in patients with cancer. Acomparison with non-cancer subjects. Int. J. Clin. Lab. Res., 30, 141.

Friedewald, W. T., Levy, R. I. and Friedrickson, D. S. (1972) Estimation of the concentration of Low density lipoprotein cholesterol in plasma, without use of the preparative ultracentrifuge. Clin. Chem., 18, 499.

Grenier, Y. and Lipshultz, S. E. (1998) Epidemiology of anthracycline cardiotoxicity in children and adults. Semin. Oncol., 25, 72.

Griese, M., Rampf, U., Hofmann, D., Führer, M., Reinhardt, D. and Bender-Götze, C. (2000) Pulmonary complications after bone marrow transplantation in children: twenty-four years of experience in a single pediatric center. Pediatr. Pulmonol., 30, 393.

Hudecová, K., Urbanová, D. and Petrásová, H. (2008) The risk of cardiovascular diseases induced by radiotherapy. Vnitr. Lek., 54, 646.

Jones, D. P., Spunt S. L., Green, D. and Springate, J. E. (2008) Renal late effects in patients treated for cancer in childhood: A report from the children's oncology group. Pediatr. Blood Cancer., 51, 724.

Mitby, P. A., Robison, L. L., Whitton, J. A., Zevon, M. A., Gibbs, I. C., Tersak, J. M., Meadows, A. T., Stovall, M., Zeltzer, L. K. and Mertens, A. C. (2003) Utilization of special education services and educational attainment among long-term survivors of childhood cancer: a report from the Childhood Cancer Survivor Study. Cancer., 97, 1115.

Mohri, H., Harano, H. and Okubo, T. (1997) Concomitant association of myasthenia gravis and pure red cell aplasia after chemotherapy for Hodgkin's disease. Am. J. Hematol., 45, 343.

Morris, R. B., Partap, S., Yeom, K., Gibbs, I. C., Fisher, P. G. and King, A. A. (2009) Views and Reviews. Cerebrovascular disease in childhood cancer survivors. A Children's Oncology Group. Neurology., 73, 1906.

Munker, R., Hasenclever, D., Brosteanu, O., Hiller, E. and Diehi, V. (1995) Bone marrow involvement in Hodgkin's disease: an analysis of 135 consecutive cases. German Hodgkin's Lymphoma Study Group. J. Clin. Oncol., 13, 403.

Musolino, C., Calabro, L., Bellomo, G., Cincotta, M., DiGiacomo, V., Pezzano, B., Rizzo,V., Guglielmo, S. and Alonci, A. (2002) Lipid profile in haematologic neoplasms. Recenti. Prog. Med., 93, 298.

Omoti, C. E. and Idogun, E. S. (2009) Serum Lipid and Lipoprotein Profile in Nigerian Patients with Haematological Malignancies. Int. J. Health. Res., 2, 267.

Egypt. J. Rad. Sci. Applic., Vol. 24, No. 2 (2011) 
Pein, F., Sakiroglu, O., Dahan, M., Lebidois, J., Merlet, P., Shamsaldin, A., Villain, E., de Vathaire, F., Sidi, D. and Hartmann, O. (2004) Cardiac abnormalities 15 years after adriamycin therapy in 229 childhood survivors of a solid tumour at the Institut Gustave Roussy. Br. J. Cancer., 91, 37.

Reid, T. J. $3^{\text {rd }}$., Mullaney, M., Burrell, L. M., Redmond, J. $3^{\text {rd }}$. and Mangan, K. F. (1994) Pure red cell aplasia after therapy for Hodgkin's lymphoma: in vitro evidence for $\mathrm{T}$ cell mediated suppression of erythropoiesis and response to sequential cyclosporin and erythropoietin. Am. J. Hematol., 46, 48.

Talvensaar, K. K., Knip, M., Lanning, P. and Lanning, M. (1996) Clinical characteristics and factors affecting growth in long-term survivors of cancer. Med. Pediatr. Oncol., 26, 166.

Tukenova, M., Guibout, C., Oberlin, O., Doyon, F., Mousannif, A., Haddy, N., Guérin, S., Pacquement, H., Aouba, A., Hawkins, M., Winter, D., Bourhis, J., Lefkopoulos, D., Diallo, I. and de Vathaire, F. (2010) Role of cancer treatment in long-term overall and cardiovascular mortality after childhood cancer. J.Clin.Oncol., 28. 1308.

van Beek, R. D., van den Heuvel-Eibrink, M. M., Hakvoort-Cammel, F. G., van den Bos, C., van der Pal, H. J., Krenning, E. P., de Rijke, Y. B., Pieters, R. and de Muinck Keizer-Schrama, S. M. (2009) Bone Mineral Density, Growth, and Thyroid Function in Long-Term Survivors of Pediatric Hodgkin's Lymphoma Treated with Chemotherapy Only. J. Clin. Endocrinol. Metab., 94, 1904.

Vordermark, D., Seufert, I., Schwab, F., Kölbl, O., Kung, M., Angermann, C. and Flentje, M. (2006) 3-D reconstruction of anterior mantle-field techniques in Hodgkin's disease survivors: doses to cardiac structures. Radiat. Oncol., 1, 10.

Winters, R., Winters, A., and Amedee, R. G. (2010) Statistics: a brief overview. Ochsner. J., 10, 213.

Yang, X., So, W., Ko, G. T., Ma, R. C., Kong, A. P., Chow, C. C., Tong, P. C. and Chan, J. C. (2008) Independent associations between low-density lipoprotein cholesterol and cancer among patients with type 2 diabetes mellitus. C.M.A. J., 179, 427.

(Received: 12/02/2012;

accepted: 27/03/2012)

Egypt. J. Rad. Sci. Applic., Vol. 24, No. 2 (2011) 


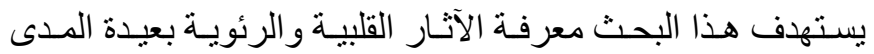

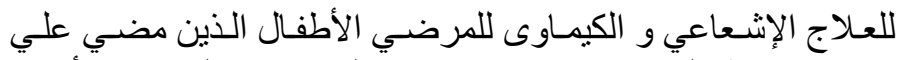

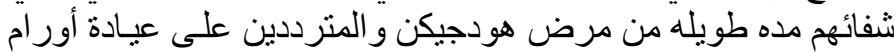
الأطفال بالمعهد القومى للأور ام التابع لجامعة القاهر هامئ

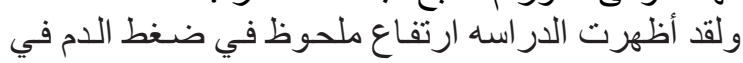

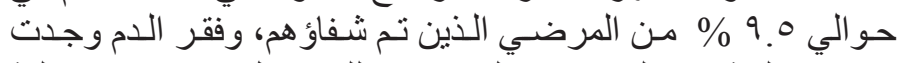

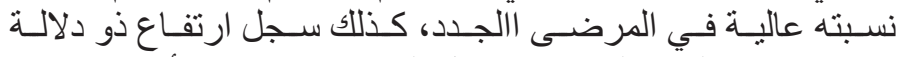

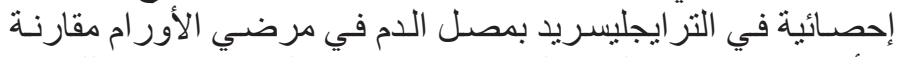

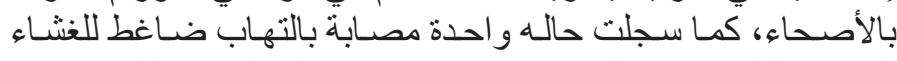

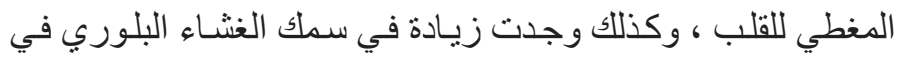

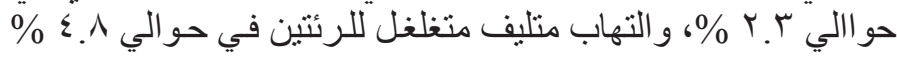

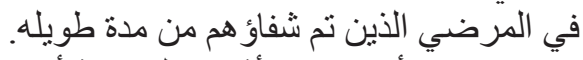

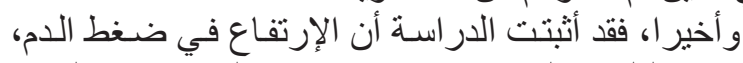

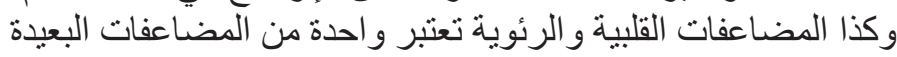

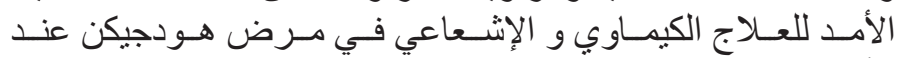

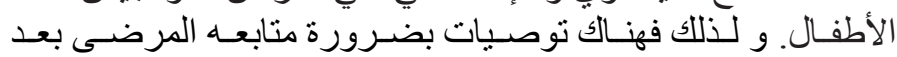

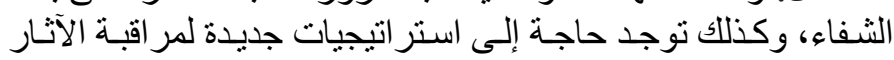

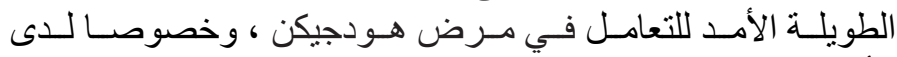

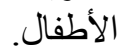

Egypt. J. Rad. Sci. Applic., Vol. 24, No. 2 (2011) 